\title{
PELATIHAN PENGGUNAAN MEDIA PEMBELAJARAN BERBASIS IT DI MADRASAH DINIYAH
}

\author{
Ana Ahsana El-Sulukiyyah ${ }^{1}$, Lilik Sugianti ${ }^{2}$, Rasyidah Nur Aisyah ${ }^{3}$ \\ ${ }^{1,2,3)}$ Program Studi Pendidikan Bahasa Inggris, Fakultas Pedagogi dan Sains, Universitas PGRI Wiranegara \\ e-mail: aahsana3@gmail.com, lilik.sugianti2017@gmail.com, ocicyah@gmail.com
}

\begin{abstract}
Abstrak
Untuk bisa mencetak generasi bangsa yang berwawasan, berahkalaqul kharimah, dan memiliki keterampilan yang siap bersaing di era revolusi industry 4.0, Madrasah Diniyah dituntut adanya transformasi metode pembelajaran konvensional menuju pembelajaran berbasis IT. Akan tetapi, kenyataannya masih jarang Madrasah Diniyah di Indonesia menerapkan media pembelajaran berbasis IT. Sehingga generasi $\mathrm{Z}$ dan Alfa yang tengah menuntut ilmu di Madrasah Diniyah merasa bosan dan tidak termotivasi untuk mengikuti pembelajaran dengan baik. Untuk mewujudkan pembelajaran yang menyenangkan dan memotivasi anak didik dari generasi $\mathrm{Z}$ dan Alfa, maka diadakan kegiatan pengabdian masyarakat yang dilaksanakan oleh individu dari peserta KKN-DR Universitas PGRI Wiranegara Pasuruan didampingi oleh Dosen Pembina Lapangan di Madin Bani Abdullah. Kegiatan ini bertujuan untuk menerapkan dan mengembangkan media pembelajaran berbasis IT melalui media pembelajaran Bahasa Arab "Applikasi Secil Bahasa Arab". Metode yang digunakan terdiri dari enam tahap yakni tahap persiapan, pendampingan, praktik penerapan media pembelajaran berbasis IT, evaluasi materi yang telah dilatihkan, kuesioner, dan analisa. Setelah melalui beberapa tahapan kegiatan tersebut terdapat peningkatan yang dicapai antara lain: (a) meningkatnya pengetahuan para santri/santriwati workshop tentang media pembelajaran berbasis IT dan Applikasi Secil Bahasa Arab serta cara menggunakannya, (b) meningkatnya antusias dan motivasi peserta pendampingan dengan pelajaran Bahasa Arab, (c) meningkatnya kosakata Bahasa Arab peserta pendampingan, (d) meningkatnya nilai akademis Bahasa Arab para peserta pendampingan melebihi nilai rata-rata Kiteria Ketuntasan Minimal (KKM) Madin Bani Abdullah. Secara ringkas dapat disimpulkan bahwa kegiatan pengabdian ini telah berhasil meningkatkan minat, antusias, motivasi para santri/santriwati terhadap pembelajaran Bahasa Arab yang mempengaruhi nilai akademis dan kemampuan mahir terhadap Bahasa Arab.
\end{abstract}

Kata Kunci: Berbasis IT, Media Pembelajaran, Madrasah Diniyah, Pelatihan

\begin{abstract}
To be able to produce generations of the nation that has insight, a good attitude, and skills that are ready to compete in the industrial revolution 4.0, Madrasah Diniyah is required to transform conventional learning into IT-based learning. However, the reality was Madrasah Diniyah in Indonesia rarely applies IT-based learning. As a result, generation $\mathrm{Z}$ and Alfa who are currently studying at Madrasah Diniyah bored. They are not motivated to follow the lessons as well. To create fun learning that can motivate the students from generation $\mathrm{Z}$ and Alfa, so the community service activities were held which were carried out by individuals from KKN-DR participants of PGRI Wiranegara University supported by a Supervising Lecturer at Madin Bani Abdullah. This activity aimed to implement and develop IT-based learning through Secil Bahasa Arab Application. The method used in this program consists of six-steps, including preparing, mentoring, practicing on implementing IT-based learning, evaluating the material that has been trained, giving questionnaires, and doing analysis. After going through several stages of the activity, several improvements were achieved by participants, including (a) increasing knowledge of the students in the workshop about IT-based learning and the Secil Bahasa Arab Application and how to use it, (b) increasing enthusiasm and motivation of the participants with Arabic lessons, (c) increasing the Arabic vocabulary of the participants, (d) increasing the Arabic's academic scores of the participants which are exceeding Madin Bani Abdullah's average minimum completeness criteria (KKM). In summary, it can be concluded that this community service activity has succeeded in increasing the interest, enthusiasm, and motivation of the students towards Arabic learning which affected the academic scores and proficiency in Arabic.
\end{abstract}

Keywords: IT-Based, Instructional Media, Madrasah Diniyah, Training 


\section{PENDAHULUAN}

Madrasah Diniyah (Madin) merupakan sebuah lembaga pendidikan keagamaan pada jalur di luar sekolah yang memiliki ciri khas pesantren. Madrasah Diniyah (Madin) terdiri dari tiga macam. Pertama, Madin yang berada di pondok pesantren dengan kurikulum mandiri dengan target sangat tinggi intelektualitasnya yaitu tafagguh fiddin (pendalaman ilmu agama) untuk mempersiapkan lahirnya dan faqiih fi mashalihil khalqi (paham, peka, dan peduli terhadap kemaslahatan dan kesejahteraan makhluk. Kedua, Madin yang berada di sekitar pondok pesantren dengan target utamanya untuk melahirkan ulama masa depan dengan kemuliaan akhlak (makarimul akhlak) dan berwawasan. Ketiga, Madin yang ada di kampung-kampung yang jauh dari pondok pesantren dengan target utamanya adalah memperbaiki akhlakul karimah, menambah wawasan pengetahuan, dan memiliki keterampilan. Dan kebanyakan ketiga macam Madrasah Diniyah di Indonesia ini masih langka dalam menerapkan Madrasah Diniyah berbasis IT.

Madrasah Diniyah (Madin) Bani Abdullah termasuk tipe madin ke-tiga yang terletak di kampung Bakalan-Pagak di Kabupaten Pasuruan, Jawa Timur. Madin Bani Abdullah mengajarkan beberapa materi keagamaan, salah satunya Bahasa Arab. Dalam pengajaran Bahasa Arab, Madin Bani Abdullah selama ini masih mempertahankan tradisi pengajaran khas ala pesantren yang klasik seperti bandongan dan sorogan. Selain itu, Madin Bani Abdullah masih mempertahankan metode pengajaran dengan teacher center (konvensional) dan belum pernah menerapkan metode pembelajaran berbasis IT.

Madin Bani Abdullah saat ini juga tengah mendidik generasi $\mathrm{Z}$ dan Alfa. Generasi $\mathrm{Z}$ dan Alfa merupakan generasi yang sudah melek teknologi. Mereka lebih menyukai metode belajar dengan cara bereksperimen atau melakukan praktek dengan memanfaatkan berbagai macam teknologi daripada duduk berdiam di kelas untuk mendengarkan penjelasan gurunya dalam durasi yang lama. Selain itu, di Madin Bani Abdullah, materi Bahasa Arab masih disampaikan dengan cara konvensional dan terpusat pada guru. Guru masih menuliskan beberapa materi kosakata Bahasa Arab di papan tulis dan para peserta didik mencacat di buku tulis dan menghafalkannya. Dengan sistem pembelajaran yang masih konvensional, peserta didik akan bosan dan enggan mengikuti pembelajaran di Madin. Dengan demikian, materi yang disampaikan tidak dapat diserap dengan baik oleh anak didik dari generasi $\mathrm{Z}$ dan Alfa. Apalagi di masa pandemik COVID-19 ini, Madin Bani Abdullah harus mengurangi jam pengajaran yang tadinya 1 jam menjadi 30 menit, sehingga waktu pengajaran tidak efisien dengan metode pengajaran konvensioanal. Selain itu, Apalagi pada perkembangan jaman semakin modern, lebih-lebih di era revolusi industri 4.0 ini, dimana era digital memegang peranan penting di lini kehidupan manusia, menuntut adanya transformasi pendidikan di Madin Bani Abdullah.

Sehingga untuk menghadapi tantangan perubahan zaman, modernitas, dan generasi peserta didik dalam mewujudkan lulusan yang memiliki kompeten yang unggul dalam Bahasa Arab di Madrasah Diniyah (Madin) Bani Abdullah, maka dilakukan pengabdian yakni pelatihan penerapan media pembelajaran berbasis IT melalui media pembelajaran Bahasa Arab "Applikasi Secil Bahasa Arab" yang dilanjutkan dengan penerapan media pembelajaran tersebut di kelas Bahasa Arab. Media pembelajaran berbasis IT merupakan media pembelajaran yang memanfaatkan kecanggihan teknologi dalam menunjang pencapaian tujuan pembelajaran dan target pembelajaran (Muhson, 2010). Media pembelajaran berbasis IT dapat berupa memanfaatkan kecanggihan teknologi dan beberapa fitur yang ada di smartphone, komputer, internet, $C D$ room/flashdisk, dll (Usman, 2017). Salah satu media pembelajaran berbasis IT yang memanfaatkan smartphone dan internet adalah Applikasi Secil Bahasa Arab. Applikasi Secil Bahasa Arab adalah serial aplikasi pendidikan untuk anak-anak yang dapat membantu belajar bahasa arab melalui benda di sekitar kita dengan cara yang menyenangkan, lengkap dengan gambar animasi dan suara. Applikasi Secil Bahasa Arab merupakan sebuah media applikasi berbasis animasi yang dapat dimanfaatkan dalam menunjang pembelajaran lebih efektif dan efisien. Selain materi dalam Bahasa Arab, Applikasi Secil Bahasa Arab juga terdapat fitur game yang menarik, antara lain game tebak kata Arab, tebak angka, dan puzzle kartu Arab.

Pengabdian di Madin Bani Abdullah ini dilakukan oleh Mahasiswa KKN-DR (Kuliah Kerja Nyata-Dari Rumah) dengan bimbingan dari Dosen Pembimbing Lapangan (DPL) kemudian melakukan pendampingan dalam penerapan media pembelajaran berbasis IT untuk meningkatkan rasa senang, antusias, motivasi dalam pembelajaran, dan kemampuan Bahasa Arab sehingga menghasilkan lulusan yang memiliki kompeten yang unggul dalam Bahasa Arab. 
Dalam observasi awal ditemukan bahwa banyak peserta didik yang merasa bosan disaat harus membaca nyaring dan menghafalkan beberapa kosa kata yang telah ditulis di papan tulis, peserta didik tidak mengidahkan penjelasan gurunya dan ramai sendiri, dan beberapa peserta didik malas untuk mencacat beberapa materi Bahasa Arab. Selain itu, pembelajaran Bahasa Arab dengan metode konvensional (teacher center) dan monoton sangat tidak efisien karena waktu habis untuk mencatat sehingga banyak anak didik yang tidak dapat menyerap materi dengan baik dan meningkatkan jumlah kosakata Bahasa Arab. Dengan adanya beberapa permasalahan tersebut ada sekitar 36\% dari jumlah siswa satu kelas memiliki kemampuan Bahasa Arab dibawah Standar Kompetensi Madin Bani Abdullah. Beberapa hasil observasi tersebut dibenarkan oleh Barni (2019), generasi Alfa akan bosan jika pendidik menggunakan sistem pembelajaran konvensional dan ini merupakan tantangan pendidik di era millennial. Menurut Utomo (2013), pembelajaran Bahasa Arab dengan metode konvensional dan monoton dapat membuat anak didik menjadi bosan dan kesulitan memahami materi. Seperti dijelaskan sebelumnya, proses belajar dan mengajar Bahasa Arab dibutuhkan media pembelajaran berbasis IT sehingga merangsang motivasi anak didik dalam belajar. Menurut Rani (2017), model pembelajaran Bahasa Arab yang efektif dengan menggunakan media pembelajaran berbasis IT sangat dibutuhkan untuk menarik anak didik untuk belajar Bahasa Arab. Para anak didik yang termotivasi dan tertarik akan menjadikan mereka senang pada pelajaran Bahasa Arab sehingga ada keinginan untuk belajar terus menerus dan ketekunan dalam mendalami pengetahuan Bahasa Arab (Zaben dan Altawalbeh, 2020). Media pembelajaran berbasis IT juga sebagai motivator learning bagi peserta didik dan mediator pada materi-materi yang memerlukan penjelasan di kalangan peserta didik (Ritonga, Nazir, dan Wahyuni, 2016).

Melihat beberapa masalah yang terdapat pada pembelajaran Bahasa Arab ini, maka pengabdi menyimpulkan untuk memberikan pendampingan dengan memberikan pengetahuan dan memperkenalkan media pembelajaran berbasis IT dengan melalui penerapan media pembelajaran Bahasa Arab "Applikasi Secil Bahasa Arab" serta praktek penerapan media pembelajaran tersebut di kelas Bahasa Arab.

\section{METODE}

Metode yang dipakai pada kegiatan pengabdian kepada masyarakat ini adalah metode pelatihan. Sasaran dan peserta pendampingan dari pengabdian ini adalah santri dan santriwati Madrasah Diniyah (Madin) Bani Abdullah Pasuruan, kelas 2 dengan peserta didik 17 orang yang meliputi 8 santri dan 9 santriwati.. Kegiatan pengabdian masyarakat yang mengambil metode pelatihan ini terbagi menjadi 6 tahapan, yakni tahap persiapan, pendampingan, praktek dalam penerapan media pembelajaran berbasis IT di kelas Bahasa Arab, evaluasi materi yang diajarkan, kuisioner, dan analisa, dengan rincian sebagai berikut:

a. Tahap Persiapan

Pada tahap ini, mahasiswa individu KKN-DR Universitas PGRI Wiranegara Pasuruan didampingi oleh Dosen Pembimbing Lapangan (DPL) melakukan observasi pada kegiatan belajar dan mengajar Bahasa Arab di Madrasah Diniyah (Madin) Bani Abdullah Pasuruan. Observasi yang dilakukan adalah model take note, dimana pengabdi mencatat metode dan media apa saja yang diterapkan dan diperlukan untuk menunjang proses pembelajaran Bahasa Arab yang belum pernah diterapkan dan digunakan oleh sasaran. Selanjutnya pengabdi menyiapkan untuk memberikan workshop tentang pengetahuan dasar media pembelajaran berbasis IT, salah satunya dengan media pembelajaran Bahasa Arab berbasis animasi "Secil Bahasa Arab".

b. Tahap Pendampingan

Tahap pendampingan merupakan tahap pemberian pengetahuan dasar tentang media pembelajaran berbasis IT, salah satunya media pembelajaran "Applikasi Secil Bahasa Arab dan praktek awal penggunaan Applikasi Secil Bahasa Arab. Tahap ini dibagi menjadi dua sesi yakni (1) sesi workshop, pada sesi ini pengabdi memberikan workshop pengetahuan dasar tentang media pembelajaran berbasis IT, salah satunya dengan media pembelajaran Bahasa Arab berbasis animasi "Secil Bahasa Arab", (2) sesi pendampingan, sesi ini pengabdi mendampingi peserta pendampingan untuk praktek mengunduh applikasi di play-store pada smartphone dan cara menggunakan Applikasi Secil Bahasa Arab. Pada pengabdian kali ini karena sasarannya adalah 17 peserta pendampingan dengan 11 smartphone maka 1 smartphone digunakan 1 atau 2 anak.

c. Tahap Praktek Penerapan Media Pembelajaran Bahasa Arab Berbasis IT di Kelas 
Dalam tahap ini, pengabdi menerapkan media pembelajaran berbasis IT yakni media pembelajaran Bahasa Arab "Secil Bahasa Arab" di kelas 2, kelas Bahasa Arab peserta pendampingan. Pada pengabdian ini, dikarenakan sasarannya adalah 17 peserta pendampingan dengan 11 smartphone maka 1 smartphone digunakan 1 atau 2 anak.

Tahap praktek ini berlangsung 3 pertemuan pada jam pembelajaran Bahasa Arab, terhitung setelah workshop diselenggarakan sampai hasil evaluasi mencapai atau melebihi nilai rata-rata KKM (Kriteria Ketuntasan Minimal) Madin Bani Abdullah yakni 7.0.

d. Tahap Evaluasi Materi yang Diajarkan

Setelah praktek penerapan media pembelajaran Bahasa Arab berbasis IT "Secil Bahasa Arab", dimana para peserta pendampingan telah diajarkan beberapa materi tema 1-3 dari Applikasi Secil Bahasa Arab, maka peserta pendampingan diberikan tes evaluasi berupa game. Tujuan dari evaluasi ini adalah untuk mengetahui bagaimana kemampuan peserta pendampingan setelah mendapat pelatihan. Sebagian besar pertanyaan berupa game mencocokan gambar berbasis animasi dan namanya dalam Bahasa Arab. Game tersebut terdapat dalam Aplikasi Secil Bahasa Arab.

e. Tahap Kuesioner

Setelah pelatihan, peserta pendampingan diberikan kuesioner. Tujuan dari kuesioner ini adalah untuk mengetahui bagaimana komentar peserta pendampingan terhadap pelatihan ini.

f. Tahap Analisa

Pada tahap ini, data yang diperoleh dari hasil evaluasi materi yang dilatihkan dan hasil kuisioner dianalisa. Analisa pada tahap ini adalah analisa kuantitatif dan kualitatif. Pada analisa kuantitatif akan dianalisa apakah nilai evaluasi materi yang diajarkan selama pelatihan telah mencapai atau melebihi nilai Kriteria Ketuntasan Minimal (KKM) Madin Bani Abdullah. Pada analisa kualitatif akan dianalisa tentang bagaimana prespektif peserta pendampingan terhadap pelatihan ini.

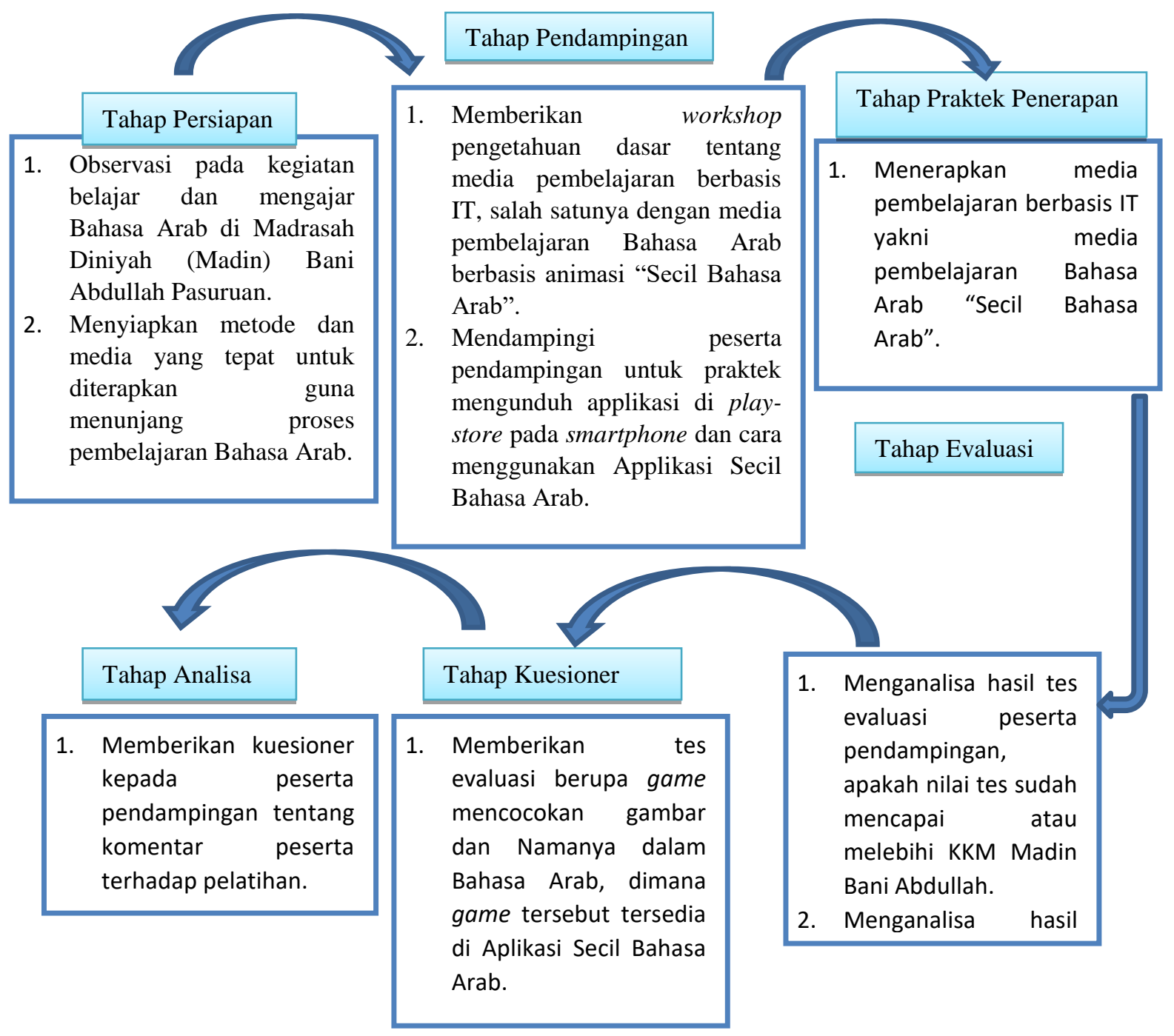


Bagan 1: Tahap Pendampingan Pelatihan Penerapan Media Pembelajaran Berbasis IT

Sasaran program pendampingan ini adalah kelas 2 Madin Bani Abdullah dengan jumlah peserta pendampingan 17 santri-santriwati, dengan rincian 8 santri dan 9 santriwati. Kegiatan pendampingan ini dilakukan selama 4 minggu yakni tanggal 15 Agustus-15september 2020, meliputi satu hari workshop (hari Rabu sesuai jadwal Bahasa Arab kelas 2) dan 3 kali pertemuan dalam 3 minggu (setiap hari Rabu sesuai jadwal Bahasa Arab kelas 2) untuk penerapan media pembelajaran Bahasa Arab berbasis IT "Applikasi Secil Bahasa Arab, dengan rincian sebagai berikut:

Tabel 1: Kegiatan pendampingan

\begin{tabular}{|c|l|}
\hline Pertemuan ke & \multicolumn{1}{c|}{ Rincian Aktivitas } \\
\hline 1 & $\begin{array}{l}\text { Workshop pengetahuan dasar tentang media pembelajaran berbasis IT, salah } \\
\text { satunya dengan media pembelajaran Bahasa Arab berbasis animasi "Secil Bahasa } \\
\text { Arab". Selain itu juga mendampingi peserta pendampingan untuk praktek } \\
\text { mengunduh applikasi di play-store pada smartphone dan cara menggunakan } \\
\text { Applikasi Secil Bahasa Arab. }\end{array}$ \\
\hline 2 & $\begin{array}{l}\text { Praktek penerapan media pembelajaran Bahasa Arab berbasis IT "Applikasi Secil } \\
\text { Bahasa Arab" di kelas 2 dengan tema "Nama Anggota Keluarga" }\end{array}$ \\
\hline 3 & $\begin{array}{l}\text { Praktek penerapan media pembelajaran Bahasa Arab berbasis IT "Applikasi Secil } \\
\text { Bahasa Arab" di kelas 2 dengan tema "Nama-nama Benda di Dalam Kelas" }\end{array}$ \\
\hline 4 & $\begin{array}{l}\text { Praktek penerapan media pembelajaran Bahasa Arab berbasis IT "Applikasi Secil } \\
\text { Bahasa Arab" dan mengadakan evaluasi dengan menerapkan game mencocokan } \\
\text { gambar dengan namanya dalam Bahasa Arab yang ada di applikasi. }\end{array}$ \\
\hline
\end{tabular}

\section{HASIL DAN PEMBAHASAN}

Kegiatan pendampingan penerapan media pembelajaran Bahasa Arab berbasis IT ini dilakukan oleh mahasiswa secara individu KKN-DR (Kuliah Kerja Nyata-Dari Rumah) dengan didampingi oleh Dosen Pembimbing Lapangan (DPL) dengan sasaran 17 santri/santriwati Madrasah Diniyah (Madin) Bani Abdullah dengan rincian 8 santri dan 9 santriwati. Pada pengabdian kali ini karena sasarannya adalah 17 peserta pendampingan dengan 11 smartphone maka 1 smartphone digunakan 1 atau 2 anak. Pada kegiatan pendampingan dibagi menjadi dua tahap, yaitu tahap workshop dan tahap praktek. Tahap workshop adalah tahap untuk memperkenalkan pengetahuan dasar tentang media pembelajaran berbasis IT, salah satunya dengan media pembelajaran Bahasa Arab berbasis animasi "Secil Bahasa Arab". Selain itu juga mendampingi peserta pendampingan untuk praktek mengunduh applikasi di play-store pada smartphone dan cara menggunakan Applikasi Secil Bahasa Arab. Para santri/santriwati dibekali materi terkait media pembelajaran berbasis IT dan contohnya. Dalam menguraikan contoh media pembelajaran berbasis IT, pengabdi memberikan contoh Applikasi Secil Bahasa Arab yang bisa di download di smartphone. Salah satu aktivitas dari kegiatan workshop pengetahuan dasar tentang media pembelajaran berbasis IT beserta contohnya, yakni Applikasi Secil Bahasa Arab tersaji dalam gambar 1.

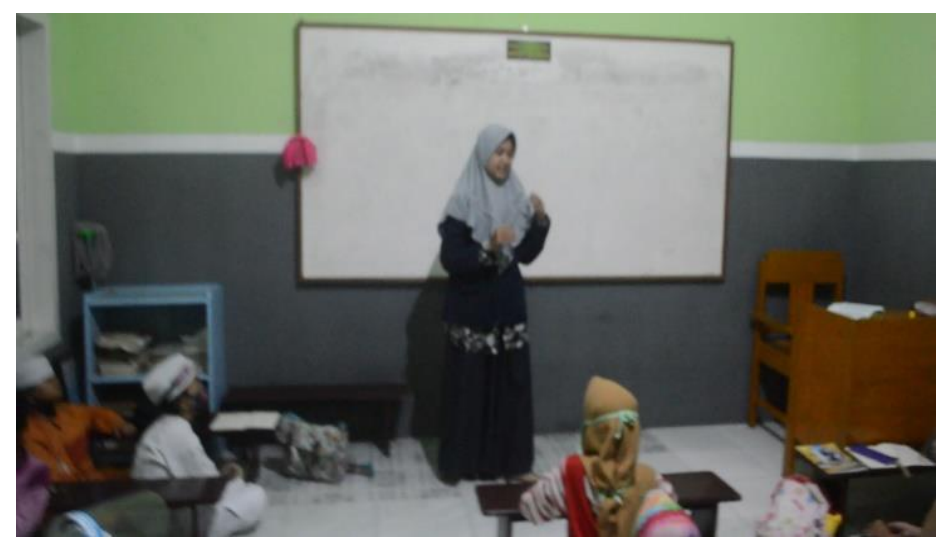


Gambar 1. Kegiatan Workshop Pengetahuan Dasar Media Pembelajaran Berbasis IT Beserta Contohnya, yakni Applikasi Secil Bahasa Arab.

Pada sesi workshop para santri/santriwati diberikan pengetahuan tentang: (a) pengertian media pembelajaran berbasis IT, (b) manfaat penggunaan media pembelajaran berbasis IT pada proses belajar di Madrasah Diniyah, (c) contoh penerapan media pembelajaran berbasis IT yang salah satunya penerapan media pembelajaran Bahasa Arab "Applikasi Secil Bahasa Arab", (d) keuntungan menggunakan Applikasi Secil Bahasa Arab dalam belajar, dan (e) fitur-fitur belajar yang ada di Applikasi Secil Bahasa Arab. Pada sesi workshop ini, terdapat sesi tanya jawab atau diskusi yang menambah pengetahuan para santri/santriwati tentang media pembelajaran berbasis IT dan Applikasi Secil Bahasa Arab. Berdasarkan observasi saat workshop sedang berlangsung, para peserta pendampingan sangat konsentrasi untuk mendengarkan penjelasan dan mereka sering bertanya tentang Applikasi Secil Bahasa Arab.

Setelah sesi workshop, sesi selanjutnya adalah sesi pendampingan. Pada sesi ini santri/santriwati dipinjami smartphone. Karena sasarannya adalah 17 peserta pendampingan dengan 11 smartphone maka 1 smartphone digunakan 1 atau 2 anak. Pada sesi ini, pengabdi mendampingi peserta pendampingan untuk praktek mengunduh applikasi di play-store pada smartphone dan cara menggunakan Applikasi Secil Bahasa Arab. Peserta pendampingan diberi informasi cara pengunduh Applikasi Secil Bahasa Arab, yaitu dengan klik icon play-store pada smartphone dan tulis Secil Bahasa Arab atau Bahasa Arab pada kolom pencarian, kemudian klik instal, maka secara otomatis Applikasi Secil Bahasa Arab terinstal dan siap digunakan. Selanjutnya, peserta pendampingan didampingi oleh pengabdi untuk praktek menggunakan Applikasi Secil Bahasa Arab, yang mana applikasi ini tidak membutuhkan jaringan internet pada saat digunakan, sehingga peserta pendampingan leluasa menggunakan applikasi ini. Berdasarkan observasi saat pendampingan sedang berlangsung, para peserta pendampingan sangat antusias untuk praktek mengunduh applikasi dan mencoba menggunakan Applikasi Secil Bahasa Arab. Salah satu aktivitas dari kegiatan pendampingan untuk praktek mengunduh Applikasi Secil Bahasa Arab dan praktek awal cara penggunaan applikasi ini, tersaji dalam gambar 2.

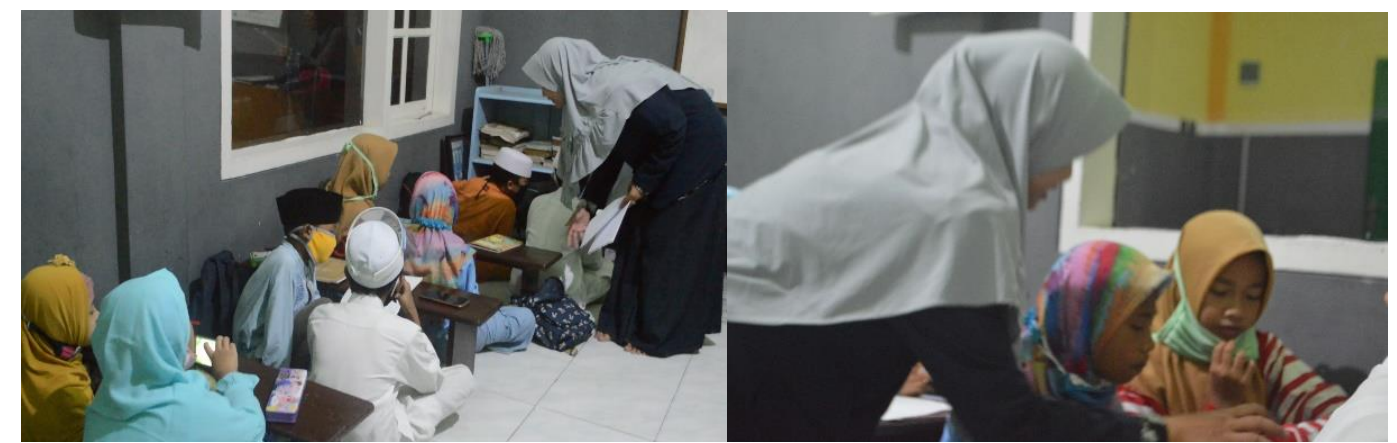

Gambar 2: Kegiatan Pendampingan untuk Praktek Mengunduh Applikasi Secil Bahasa Arab dan Praktek Awal Cara Penggunaannya

Pada tahap praktek penerapan media pembelajaran Bahasa Arab berbasis IT "Secil Bahasa Arab", para santri/santriwati target pengabdian dipinjami 11 smartphone untuk 1 atau 2 anak. Mereka dilatih menggunakan Applikasi Secil Bahasa Arab dalam 3 pertemuan, setiap hari Rabu (sesuai jadwal Bahasa Arab Madin Bani Abdullah), dengan rincian sebagai berikut: 
Tabel 2: Rincian Pelatihan Penerapan Media Pembelajaran Bahasa Arab Berbasis IT “Aplikasi Secil Bahasa Arab"

\begin{tabular}{|c|l|}
\hline Pertemuan ke & \multicolumn{3}{|c|}{ Rincian Pelatihan } \\
\hline 1 & $\begin{array}{l}\text { Praktek penerapan media pembelajaran Bahasa Arab berbasis IT } \\
\text { "Applikasi Secil Bahasa Arab" di kelas 2 dengan tema "Nama Anggota } \\
\text { Keluarga" }\end{array}$ \\
\hline 2 & $\begin{array}{l}\text { Praktek penerapan media pembelajaran Bahasa Arab berbasis IT } \\
\text { "Applikasi Secil Bahasa Arab" di kelas 2 dengan tema "Nama-nama Benda } \\
\text { di Dalam Kelas" }\end{array}$ \\
\hline 3 & $\begin{array}{l}\text { Praktek penerapan media pembelajaran Bahasa Arab berbasis IT } \\
\text { "Applikasi Secil Bahasa Arab" dan mengadakan evaluasi dengan } \\
\text { menerapkan game mencocokan gambar dengan namanya dalam Bahasa } \\
\text { Arab yang ada di applikasi. }\end{array}$ \\
\hline
\end{tabular}

Dalam pelatihan penerapan media pembelajaran Bahasa Arab berbasis IT "Secil Bahasa Arab", para perserta pendampingan mendengarkan pelafalan kosakata yang terdengar dari Applikasi Secil Bahasa Arab dan menirukan untuk mengucapkan kosakata tersebut secara individu sehingga dapat menambah kosakata Bahasa Arab. Selain itu mereka dapat melihat gambar berbasis animasi yang interaktif dan sesuai dengan namanya dalam Bahasa Arab. Menurut Taufik (2020), media pembelajaran Bahasa Arab berbasis animasi itu menarik dan menghibur, sehingga merangsang motivasi untuk belajar dan ini adalah cara yang tepat untuk memperjelas makna, gagasan pokok, dan kemudahan pemahaman informasi kepada peserta didik. Dan untuk menambah pemahaman kosakata dalam Bahasa Arab, pengabdi menghimbau agar peserta pengabdian dapat belajar di rumah dengan menggunakan Applikasi Secil Bahasa Arab pada smartphone mereka sendiri. Salah satu aktivitas dari kegiatan praktek penerapan media pembelajaran Bahasa Arab berbasis IT "Secil Bahasa Arab" di kelas tersaji dalam gambar 3.

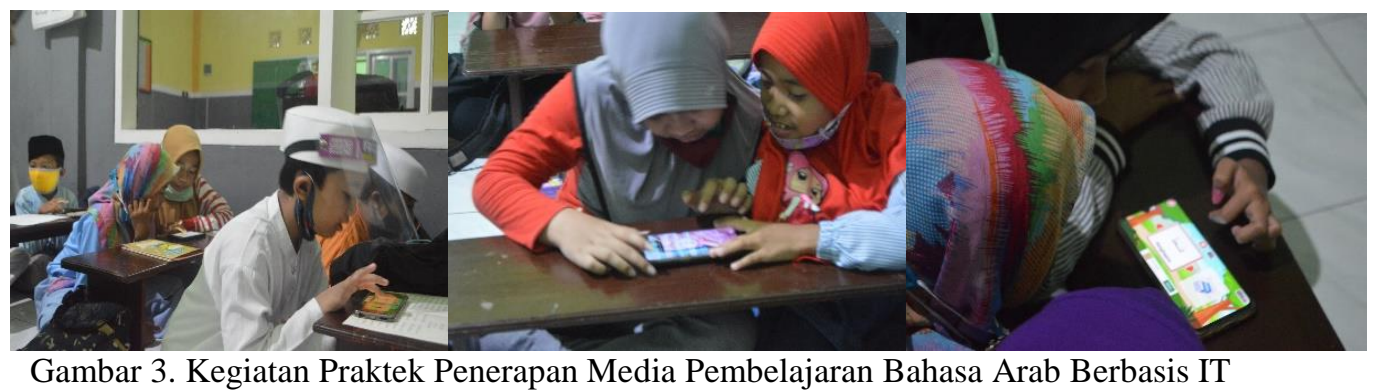

"Secil Bahasa Arab" di kelas

Setelah para peserta target pengabdian mendapat pelatihan, mereka diberikan tes evaluasi dengan memainkan game. Game tersebut tentang mencocokan gambar berbasis animasi dan namanya dalam Bahasa Arab yang terdapat di Applikasi Secil Bahasa Arab. Pada pengabdian ini, para peserta pendampingan mengerjakan tiga fitur game yang ada di Applikasi Secil Bahasa Arab, yaitu game tebak kata Arab, tebak angka Arab, dan puzzle kartu Arab. Pada masing-masing game, peserta pendampingan mendengarkan petunjuk pertanyaan yang berupa audio dari Applikasi Secil Bahasa Arab. Kemudian peserta target pengabdian memilih salah satu nama gambar itu pada tiga nama dalam Bahasa Arab. Jika jawaban benar maka mendapatkan nilai 10 dan jika salah akan dikurangi 2. Nilai akan secara otomatis diakumulatifkan dari soal pertama hingga selesai. 


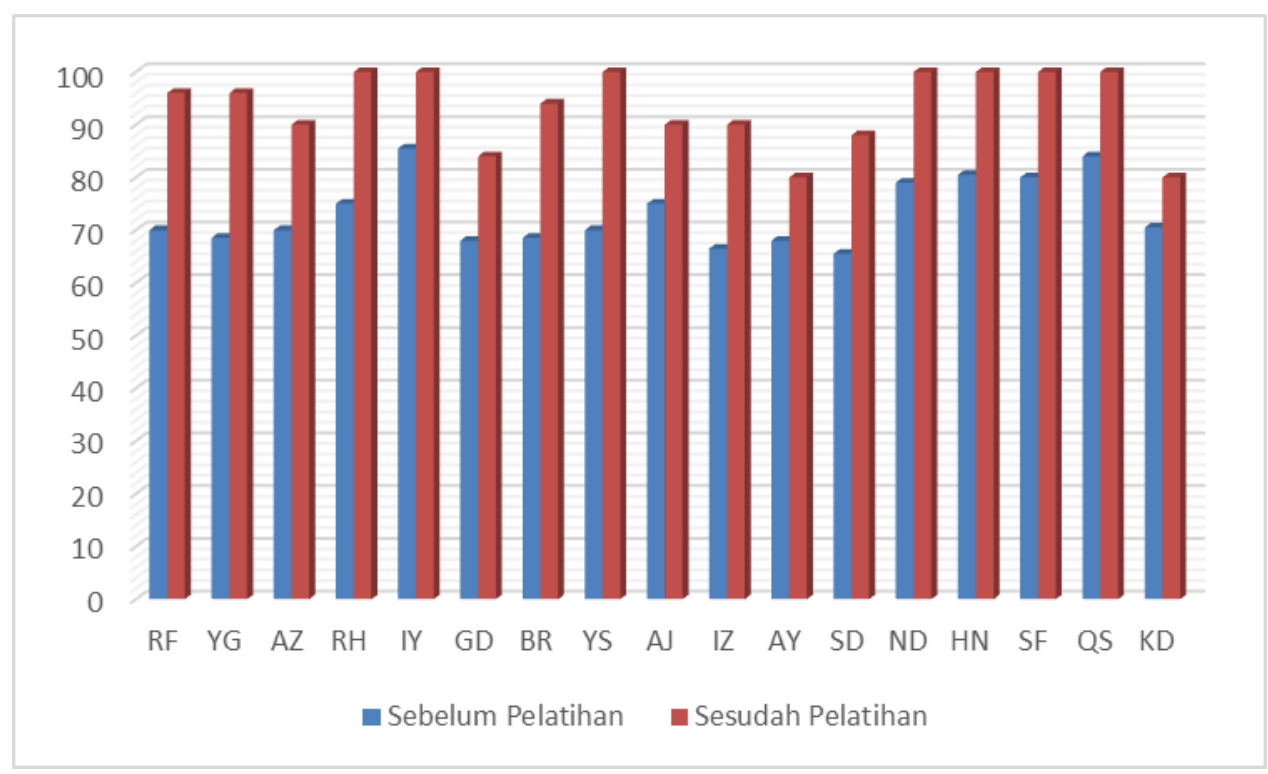

Bagan 2: Peningkatan Nilai Akademik Bahasa Arab

Setelah menyelesaikan tiga fitur game yang terdapat di Applikasi Secil Bahasa Arab, nilai tes evaluasi para santri/santriwati peserta pendampingan diatas nilai rata-rata KKM (Kriteria Ketuntasan Minimal) Madin Bani Abdullah, yakni 7.0. Menurut Muna (2018), media pembelajaran Bahasa Arab berbasis animasi dapat membantu meningkatkan prestasi akademik, mengembangkan pemikiran, dan keterampilan kognitif karena media pembelajaran berbasis animasi dapat digunakan dalam pendidikan karena menyederhanakan kompleksitas, memperjelas ketidakjelasan, dan memfasilitasi pemahaman indrawi dengan konsep abstrak.

Persepsi peserta pendampingan terhadap pelatihan penerapan media pembelajaran berbasis IT yang di dapat dari kuesioner diantaranya adalah menyenangkan, sangat membantu dalam belajar dan menambah kosakata Bahasa Arab, sangat menarik, menambah wawasan baru, sangat bermanfaat, luar biasa dan berkesan, membuat penasaran, sangat bagus, dan bagus. Sebagian besar harapan peserta pendampingan terhadap pelatihan ini adalah agar pelatihan ini diadakan kembali dengan durasi pelatihan yang lebih lama dan materi yang lebih banyak lagi.

\section{SIMPULAN}

Peningkatan-peningkatan terlihat pada kegiatan pelatihan ini yaitu: (a) meningkatnya pengetahuan para santri/santriwati workshop tentang media pembelajaran Bahasa Arab berbasis IT, (b) meningkatnya pengetahuan para santri/santriwati peserta pendampingan tentang applikasi Secil Bahasa Arab dan cara menggunakannya, (c) meningkatnya antusias dan motivasi para santri/santriwati peserta pendampingan dengan pelajaran Bahasa Arab, (d) meningkatnya kosa kata Bahasa Arab para peserta pendampingan, (e) meningkatnya nilai akademis Bahasa Arab para peserta pendampingan melebihi nilai rata-rata KKM (Kriteria Ketuntasan Minimal) Madin Bani Abdullah.

Kegiatan ini juga telah merubah pemikiran para santri/santriwati yang dulunya berfikir belajar Bahasa Arab itu sulit karena bukan bahasa keseharian dan belajar Bahasa Arab itu membosankan karena penuh dengan tulis-menulis dan hafalan. Namun sekarang, mereka dengan antusias, senang, dan penuh motivasi mengikuti pembelajaran, serta mudah memahami materi sehingga target pembelajaran di Madin Bani Abdullah tercapai. Harapan selanjutnya, sepeninggalan pengabdi (Mahasiswa KKN-DR) metode pembelajaran dengan media berbasis IT dan cara penerapannya tersebut dapat senantiasa berguna dan digunakan oleh para santri/santriwati yang didampingi oleh Ustadzah Bahasa Arab agar kelak mereka lulus akan memiliki skill Bahasa Arab yang mumpuni. Selain itu, mereka juga berwawasan pengetahuan, berakhalaqul kharimah, dan cinta tanah air. 


\section{SARAN}

Para pengabdi masyarakat selanjutnya dapat memberikan pelatihan IT yang memuat tentang aktifitas pendidikan atau permainan pada mata pelajaran lain, sehingga dapat memperkaya khasanah pembelajaran berbasis it di Madrasah Diniyah.

\section{UCAPAN TERIMA KASIH}

Kegiatan pengabdian pada masyarakat ini merupakan kegiatan secara individu KKN-DR Universitas PGRI Wiranegara Pasuruan. Oleh karenanya, penulis yang juga sebagai pengabdi mengucapkan terima kasih yang tak terhingga kepada Pembina Madrasah Diniyah Bani Abdullah dan Ustadzah Bahasa Arab yang dengan senang hati bekerja sama atas terlenggaranya program pendampingan ini, juga terima kasih atas bimbingan yang telah diberikan oleh Ibu Dosen Pembimbing Lapangan (DPL) yang selama kurang lebih satu bulan melakukan pembimbingan.

\section{DAFTAR PUSTAKA}

Barni, Mahyuddin. (2019). Jurnal Transformatif, Vol. 3, No.1. Tantangan Pendidik Di Era Millennial. (Online) http://e-journal.iain-palangkaraya.ac.id/index.php/TF/article/view/1251. Diakses pada 16 Agustus 2020

Muhson, Ali. (2010). Jurnal Pendidikan Akuntansi Indonesia. Pengembangan Media Pembelajaran Berbasis Teknologi Informasi. (Online).

https://journal.uny.ac.id/index.php/jpakun/article/view/949. Diakses pada 28 Agustus 2020

Muna, N. (2018). The Effectiveness of Using Folklore Based Animation Median Teaching English Articles for Seventh Grade of MTs Al- Hikmah Sayung Demak in the Academic Year of 2017-2018. Education and Teacher Training Faculty, Islamic University. (Online). http://eprints.walisongo.ac.id/8436/1/skripsi\%20full.pdf. Diakses pada 20 Agustus 2020

Rani. (2017). At-Ta'dib: Vol IX, No.2. Pembelajaran Bahasa Arab Berbasis Teknologi Informasi dan Komunikasi. (Online).

http://ejournal.staindirundeng.ac.id/index.php/tadib/article/view/14/3. Diakses pada 31 Agustus 2020

Ritonga, Nazir, dan Wahyuni. (2016). Jurnal Pendidikan Bahasa Arab Kebahasaaraban, Vol.3, No.1. Pembelajaran Bahasa Arab Berbasis Teknologi Informasi dan Komunikasi di Kota Padang. (Online). http://journal.uinjkt.ac.id/index.php/arabiyat/article/view/2879/pdf.

Diakses pada 31 Agustus 2020

Taufik. (2020). Media Pembelajaran Interaktif Berbasis Adobe Flash Untuk Meningkatkan Pemerolehan Kosa Kata Bahasa Arab Siswa Masa Kini. (Online). http://prosiding.arabum.com/index.php/semnasbama/article/view/628/579. Diakses pada 1 September 2020

Usman. (2017). Jurnalisa, Vol.3, No.1. Dinamika Pembelajaran Berbasis Teknologi Informasi Pada Lembaga Pendidikan Tinggi. (Online). http://journal.uinalauddin.ac.id/index.php/jurnalisa/article/view/3065. Diakses pada 1 September 2020

Utomo. (2013). Pemanfaatan Media Pembelajaran Bahasa Arab Berbasis Macromedia Flash 8 Untuk Meningkatkan Berbicara Bahasa Arab Siswa Kelas X Man Purwodadi Grobogan. (Online). https://lib.unnes.ac.id/18343/1/2303408036.pdf. Diakses pada 30 Agustus 2020

Zaben dan Altawalbeh. (2020). Psychology and Education, 57(5): 358-361. An Interdisciplinary Journal. The Effectiveness of Using Animation on Sciences Academic Achievement of the Third Grade Students in Al-Jeezah District schools. (Online).

http://www.psychologyandeducation.net/Article/the-effectiveness-of-using-animation-on sciencesacademic-achievement-of-the-third-grade-students-in-al-jeezah-district schools.pdf. Diakses pada 26 Agustus 202 